\title{
Study of Characteristics of Bricks Produced in Kathmandu, Nepal
}

\author{
Shanti Kala Subedi \\ Himalaya College of Engineering, Tribhuvan University, Lalitpur, Nepal
}

\section{Email address:}

sksubedi3@hotmail.com

\section{To cite this article:}

Shanti Kala Subedi. Study of Characteristics of Bricks Produced in Kathmandu, Nepal. American Journal of Civil Engineering. Vol. 8, No. 3, 2020, pp. 64-76. doi: 10.11648/j.ajce.20200803.13

Received: June 14, 2020; Accepted: June 30, 2020; Published: July 6, 2020

\begin{abstract}
The quality of brick is determined by its physical, mechanical and microstructure characteristics. The main objective of this study was to assess the characteristics of different types of bricks produced under various clay composition, different types of kiln used, and various firing temperature, and cooling process, which are considered as the major factors affecting the brick quality. A mixed-method approach was used to carry out this study. Both primary and secondary data were collected form field observations, discussions, lab experiments, and literature review. Literature review was done to identify the relationship between affecting factors and brick characteristics. The status of bricks produced was assessed through lab tests. The results from both methods were compared and discussed thoroughly. The purposive sampling method was adopted to collect brick samples from six different brick factories situated in Kathmandu and lab tests were carried out in the Engineering Material Lab at Institute of Engineering (IOE) Pulchowk Campus, Lalitpur, Nepal. Deformation, bulk density, water absorption capacity, and compressive strengths of sampled bricks were observed and then compared with standard code values as well as with previous findings. The study showed that none of the brick samples was found within the standard benchmarks, and the bulk density was low, however, the water absorption capacity and compressive strength values of all the sampled bricks were found to be within the allowable limit, even though they were close to the lower bound. The study also discussed technical, social and environment policy related issues that are important for producing and making the best use of quality bricks. The study results may be applied to other places where similar situation exists.
\end{abstract}

Keywords: Brick Quality, Bulk Density, Water Absorption Capacity, Compressive Strength

\section{Introduction}

\subsection{Background}

The demand for brick is accelerating worldwide, mainly due to rapid urbanization and associated socio-economic development. Urbanization is increasing at an average rate of $6 \%$ per annum, driving the demand for bricks for housing commensurately [1]. More than 1.5 trillion bricks are produced globally each year. Of these, 1.35 billion bricks (or $89 \%$ ) are from Asia, and Nepal accounts for $1.81 \%$ of it [2]. Brick production rate in Nepal has increased sharply by $87.5 \%$ between 2009 and $2012[3,2]$ and it is increasing more drastically after devastating earthquake in 2015 [4]. Brick production in such a spectacular speed has been raising serious concern about the deteriorating brick quality [5], as most of the entrepreneurs jump for at any opportunities for making quick profits, but providing less attention in quality production [2].

Quality of brick is determined by its characteristics, which is mainly influenced by composition of the raw materials, type of the brick kilns, the firing time, firing temperature, and overall cooling process (Figure 1). Characteristics of brick can be assessed through lab tests by following standard codes like Bureau of Indian Standard (BIS), American Society for Testing Materials (ASTM), and Nepal Standard Building (NSB).

A number of studies about characteristics of bricks have been done before $[1,2,6,7,8,9]$, however, none of them have assessed the quality of brick with respect to all influencing factors together $[1,9]$ which this study aims to address. Though, this case study was performed on the bricks produced in Kathmandu Valley, the result would be applicable to other places where similar conditions exist. 


\subsection{Research Objectives}

This study aimed to contribute on quality brick production and its use. The specific objectives of this study were:

1. To review major affecting factors in brick manufacturing process

2. To examine the characteristics of bricks and assess their quality

3. To discuss the potential way of increasing brick production quality

\subsection{Research Questions}

1. What are the major technical factors affecting quality of the brick or characteristics?

2. What are the physical and mechanical characteristics of bricks? Are the bricks qualified with the standard threshold value?

3. How do various social, economic and environmental factors affect quality brick production?

\section{Literature Review}

\subsection{Technical Factors Affecting Brick Characteristics}

The size, shape, color, bulk density, water absorption capacity and mechanical strength are the major characteristics of brick that vary on bricks manufactured at different production conditions including composition of clay, type of brick kiln, firing time, and firing temperatures [10].

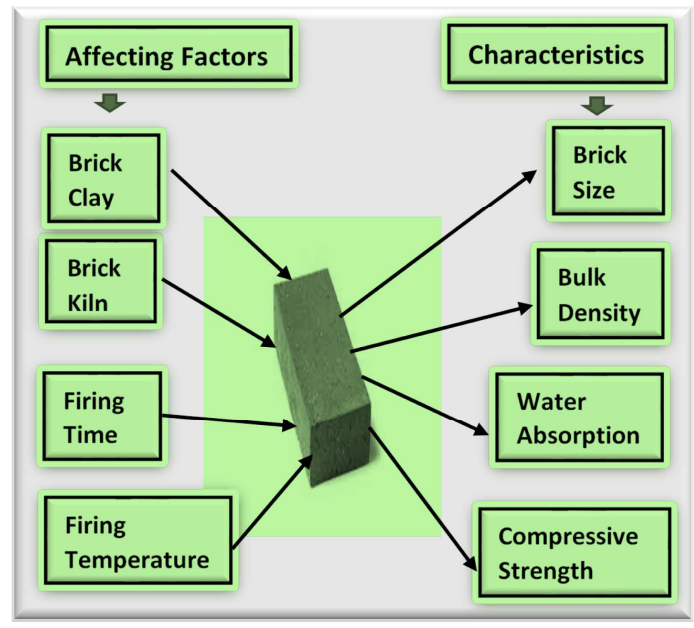

Figure 1. Factors affecting brick characteristics.

(i) Brick clay

A good brick clay should contain proper proportion of homogeneously mixed up sand, silt and clay in the proportion of 20 to $30 \%$, clay (alumina), 35 to $50 \%$ sand (silica), 20 to $25 \%$ silt, and 1 to $2 \%$ of other traces [10]. Clay contains $\mathrm{SiO}_{2}+\mathrm{Al}_{2} \mathrm{O}_{3}+$ impurities $(\mathrm{CaO})$. Clay is mixed with water $(12-15 \%$ water by weight) to produce plasticity, which forms $\mathrm{Al}_{2} \mathrm{O}_{3} \cdot 2 \mathrm{SiO}_{2} \cdot 2 \mathrm{H}_{2} \mathrm{O}$. Varying compositions have different melting points that affects infusion process of atomic bonding [10].
The fusibility of clay makes bricks hard, solid and reduce absorption capacity when properly fired. The fusioning rate of clay particles increase during vitrification process which affects bonding of microstructures. Brick characteristics are determined by the firing temperature as the common melting points for each constituent are different: silica, alumina, lime, and magnesia melts at $1713^{\circ} \mathrm{C}, 2050^{\circ} \mathrm{C}, 2570^{\circ}$, and $2800^{\circ} \mathrm{C}$ respectively [10].

The firing process converts limestone (calcium carbonate) into calcium oxide. After cooling, the calcium oxide becomes strongly reactive with water vapor. This converts the calcium oxide into calcium hydroxide with an attendant enormous expansion in volume. Clay composition when heated, becomes sintered, and creates strong atomic bond between particles that reduce voids, and increase strengths [11]. Brick clay composition is important to be identified as it determines brick quality [12, 13], and protects from durability failure [14].

Composition of brick clay varies as per location, so it is necessary to apply a varying range of firing temperature to get the same characteristics value [15]. Availability of proper clay with appropriate composition of particles could be a challenge for brick manufacturers not only from technical but also from social, environmental and economical perspectives.

In most of the brick factories in Kathmandu Valley, because of unavailability of soil in the vicinity of brick factories, brick clay is stored near factories, and used when required (Figure 2 (a)).
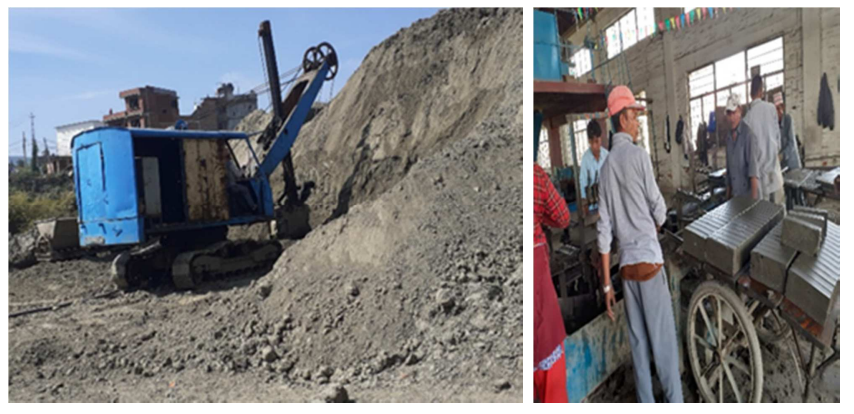

Figure 2. (a): Taking Brick clay from storage place near the factory; b) Green bricks ready to firing.

(ii) Brick Kiln

Firing, one of the most specialized steps in the manufacture of brick, requires from 40 to 150-hour firing time depending upon kiln type and other variables such as type of fuel, and consistent application of heat. The two general types of kilns- namely traditional/ intermittent and continuous- are commonly in use. Clamp Kiln (CK) is mostly used intermittent type kiln which is designed without chimney. Hoffman Kiln (HK), Fixed Chimney Bulls Trench Kiln (FCBTK) and ZigZag Kiln (ZZK) are moving fire type kilns and Vertical Shaft Brick Kiln (VSBK), and Tunnel Kilns (TK) are mostly used moving ware type continuous kiln as shown in (Figure 3).

Out of 110 brick kilns operating in Kathmandu Valley, 107 are FCBTK, 2 are HK and one is VSBK [16]. FCBTK is a newer version of the traditional Bull's Trench Kiln (BTK). It is almost 200 year-old-technology and shares about $88 \%$ of 
Nepal's total brick kilns and 97\% in Kathmandu Valley (ibid) (Figure 4). With the advances in science and technology, it is difficult for $\mathrm{HK}$ to adapt mechanical operations, however, this kiln is good from low fuel consumption and stack emission; bricks are burnt evenly and the quality of bricks is good, and sufficient height of the chimney controls the emissions. The VSBK technology has experienced a lot of difficulties comparatively as the technology requires higher management skill. The technology is also highly sensitive to the quality of clay; the production capacity of VSBK is too small; and brick quality is low and breakage rate is high. So, the dissemination of this kiln is slow.

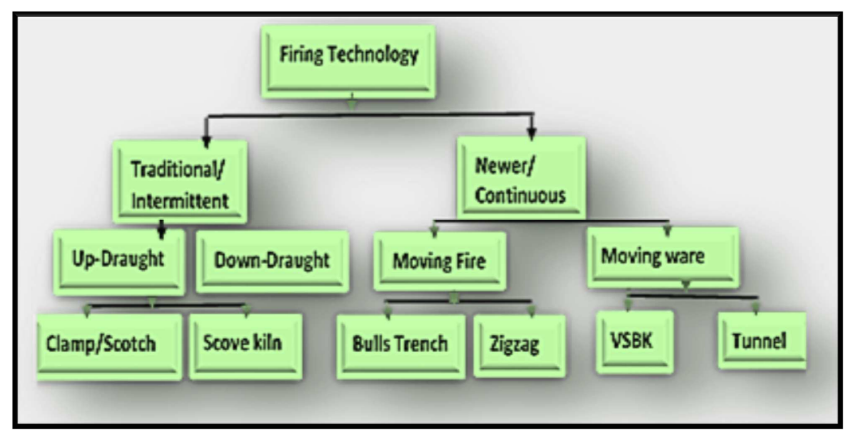

Figure 3. Brick kilns.

The choice of kiln for brick production depends on many factors (Table 1). Emission from kiln is one of the important aspects to be considered for better health and environment [5, 8]. In terms of air pollution, FCBTK is the most polluting technology like Traditional CK. HK, a Chinese technologybased kiln, has been modified to Hybrid-Hoffman Kiln (HHK) and considered as modern brick firing technology. Clamp is the most traditional brick firing technology suited mainly for small-scale brick production. It is also the second most prevalent brick firing technology. There is increasing interest and uptake of ZZK and FCBTKs after the devastating earthquake in Nepal in 2015. Nevertheless, HHK and Tunnel Kilns are considered to be the cleanest, but the number is still low $[16,17]$.

From production efficiency perspective, the consistent application of heat, that produced more $1^{\text {st }}$ class type bricks, is effective in Tunnel kiln (100\% efficiency) followed by Zigzag (up to 90\%) and Hoffman (80\% efficiency) Kilns. Though FCBTK is not good for efficiency as it produces about $40-50 \%$ unqualified bricks $[10,40]$.

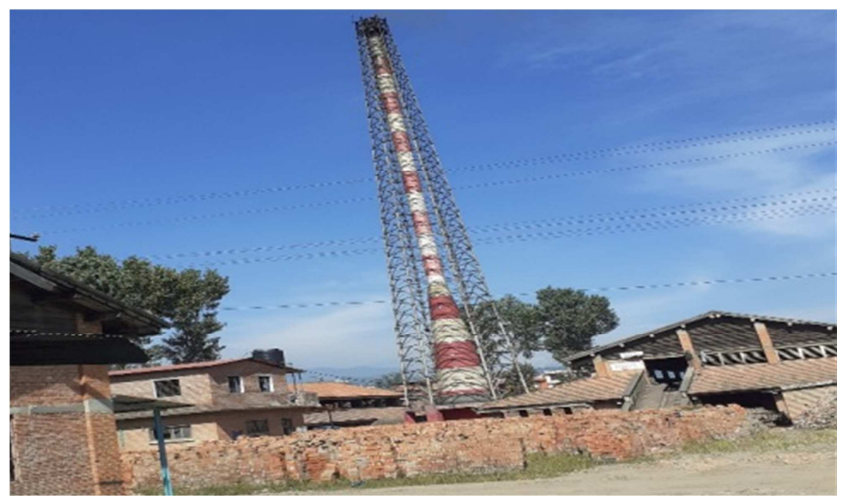

Figure 4. A One of the visited brick kilns in Bhaktapur.

The compressive strength and water absorption capacity of bricks vary as per type of kiln and position of bricks inside the kiln during firing process [18] (Figure 5).

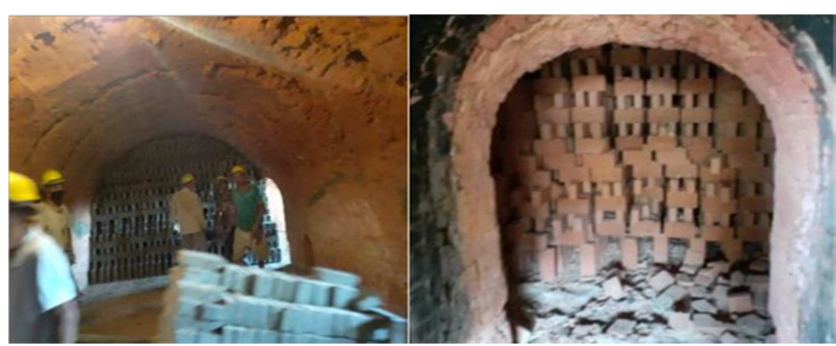

Figure 5. (a), (b): Position of bricks inside the kilns.

Table 1. Comparison of brick kiln technology.

\begin{tabular}{|c|c|c|c|}
\hline Type of brick kiln & Environment Emission & $\begin{array}{l}\text { First-Class Brick Production } \\
\text { Rate }\end{array}$ & $\begin{array}{l}\text { Underfired, Overfired or } \\
\text { Breakages }\end{array}$ \\
\hline Zigzag & $70-80 \%$ lower than FCBTK & $80-90 \%$ & $10-20 \%$ \\
\hline FCBTK & High emission of PM and gaseous potential & $50-60 \%$ & $40-50 \%$ \\
\hline Hoffman & Less emission & $80 \%$ & $20 \%$ \\
\hline Tunnel & Significantly less pollutant emission & $100 \%$ & \\
\hline Clamp kiln & Concentration of air pollution around the kiln is very high & $50-60 \%$ & \\
\hline
\end{tabular}

(iii) Brick Firing Time

Burning time depends on the type of kiln used. It takes total 2 to 6 months to burn and cool the bricks in traditional kilns, where, it takes $24 \mathrm{hrs}$. to 12 days in other kiln burning [10]. Bricks produced through fast firing process have greater mechanical strength, greater frost resistance and lower bulk density properties [12]. Shortening firing time reduce production cost and increase the productivity [19]. In the contrary, prolonged firing time had no such significant effects on the properties of bricks investigated, therefore longer firing times should be avoided to save time, cost, and energy

\section{[20].}

(iv) Brick Firing Temperature

The purpose of the burning of bricks is twofold: to increase the density of bricks so that they absorb less quantity of water; and to impart hardness and strength to the brick [10]. The fresh molded (green) bricks must be correctly dried at $40-200^{\circ} \mathrm{C}$ at $24-48 \mathrm{hrs}$. before they enter the kiln to be fired because the moisture (liquid limit) must be minimized to $25-38 \%$ to prevent from certain defects like cracks or shrinkages. During brick firing process, application of range of heat works in different steps at: a) $200^{\circ} \mathrm{C}$ to $450^{\circ} \mathrm{C}$ - water smoking up and evaporation of free water, b) $450^{\circ} \mathrm{C}$ to 
$750^{\circ} \mathrm{C}$ - dehydration or evaporation of chemically bound water; c) $750^{\circ} \mathrm{C}-950^{\circ} \mathrm{C}$ - oxidation or formation of oxide, and d) $950^{\circ} \mathrm{C}$ to $1200^{\circ} \mathrm{C}$ - vitrification process, where low melting components liquefy and fill the pores. When heat apply above $1250^{\circ} \mathrm{C}$ shrinkage and cracks appeared in bricks [10].

$800^{\circ} \mathrm{C}$ to $900^{\circ} \mathrm{C}$ temperature was not enough to experience full solid-state sintering process [20], but firing temperature up to $1000^{\circ} \mathrm{C}$ attributed to the enhanced vitrification in the clay materials so that its compressive strength increased [20]. Hence, temperature $1000-1100^{\circ} \mathrm{C}$ is considered suitable for good brick production. However, sintering becomes very significant and maximum compressive strength of brick found at optimum temperature at $1200^{\circ} \mathrm{C}$ [13]. But practically, it might not be feasible, and not necessary too to maintain $1200^{\circ}$ where $1000-1100^{\circ} \mathrm{C}$ is enough to get maximum strength.

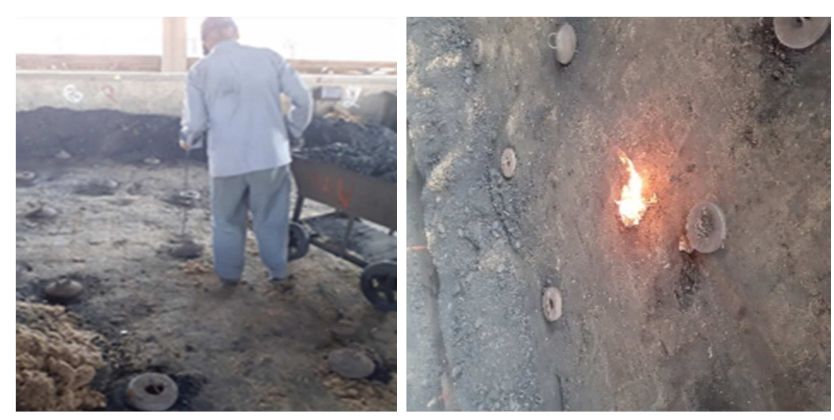

Figure 6. (a): Setting for burning fuel, b) brick burning.

(v) Burning Fuel

Coal is the main brick burning fuel including rice husk, saw dust and bagasse. The efficiency of brick kiln depends on type of fuel used to burn the brick (Figure 6). Fuel efficiency depends on consistent heating of bricks and firing time. However, the excessive use of coal is one of the primary reasons for high emissions from brick industries. Emission rate from the kiln largely depends on the design of oven, type and height of chimney and type of fuel used [16].

\subsection{Characteristics of Bricks}

Physical characteristics mainly shape, size, color, density and water absorption capacity [10] of bricks significantly influence on the mechanical properties or strength of bricks $[9,48]$.

(i) Shape, Size and Color

The standard brick size in Nepal, as per NBC 205: 1994, is $240 \times 115 \times 57 \mathrm{~mm}$ however, there is no uniformity of brick size in Nepal as the size of bricks is different in different places inside and out of the Valley [43]. Bricks in Terai are bigger in size where as those within Kathmandu Valley and Hilly Regions are smaller in size. A general perception among customers is that thicker bricks are stronger and costeffective. As a result, there is a growing tendency to produce thicker bricks to attract customers. This has direct implications on energy consumption and environment performance of brick kilns also.

While looking to international context, brick size in Nepal and Germany look similar but comparatively higher than in other countries (Table 2).

Table 2. Size of brick and standards (international).

\begin{tabular}{llll}
\hline Country & Standard & Standard size of brick (mm) & $240 \times 115 \times 57$ \\
\hline Nepal & National Building Code (NBC 205: 1994) of Nepal & $228 \times 107 \times 69$ & \\
India & Bureau of Indian standard (BIS) & $230 \times 110 \times 76$ \\
Australia & Australian Standard (AS4455) & $203 \times 92 \times 57$ \\
USA & American Society for Testing and Materials (ASTM) & & \\
\hline
\end{tabular}

(ii) Bulk Density

Bulk density determines durability of brick. It is the ratio of weight to volume [10]. Weight and volume at compact and wet condition are always greater than at porous or dry condition.

$$
\text { Bulk Density }=\frac{\text { Weight }(W)}{\text { Volume }(V)}\left(\mathrm{N} / \mathrm{m}^{3}\right)
$$

Bulk density of compact clay bricks is about $2.3-2.4$ $\mathrm{g} / \mathrm{cm}^{3}$, and of lightweight clay bricks is about $0.8-1.3 \mathrm{~g} / \mathrm{cm}^{3}$ [10].

(iii) Water Absorption (W\%)

It is the ratio of water absorbed weight to dry weight [6].

$$
\text { Water absorption }(\mathrm{w} \%)=\frac{(W 2-W 1)}{W 1} \mathrm{x} 100
$$

where $\mathrm{w}_{1}$ is the oven-dry weight of the sample, and $\mathrm{w}_{2}$ is the weight after 24 hours of immersion in water [10]. Higher absorption leads to water-related defects such as frost-action, efflorescence and dampness. (iv) Compressive Strength

Compressive strength is the resistance of material to breaking under load due to compression. The strength of brick is determined by the composition of the clay and degree of burning temperature. Compressive strength $(\mathrm{Fc})$ is the ratio of load at failure to cross sectional area.

$$
\mathrm{F}=\frac{(\text { Maximum load at failure })(\mathrm{N})}{(\text { Loaded area of brick }) \mathrm{mm} 2}
$$

(v) Classification of Bricks

Conventionally, bricks are classified into two types: a) Sun dried, and b) Burnt bricks [6]. Burn bricks are further classified into four types: i) first-class; ii) second class; iii) third-class and iv) over burnt, under burnt or breakages [10]. First class brick is a well burnt brick with regular shape, sharp edges and well- defined sizes. It is free from lumps, grid and holes with uniform compact structure. Water absorption shall not be more than $25 \%$. It does not show any efflorescence when soaked in water for 24 hours and dried in shed. It has specific gravity of 1.8 and minimum compressive strength of $10.5 \mathrm{MPa}$ (105 
$\mathrm{kg} / \mathrm{cm}^{2}$ ). Normally it uses in carvings, arches and copings. Second class brick has the similar physical characteristics with first class brick; however, its specific gravity is 1.8 , water absorption capacity is $22 \%$ and minimum compressive strength is $7.5 \mathrm{~N} / \mathrm{mm}^{2}$. It mostly applies for internal use where the bricks are generally hidden from views. The third-class bricks are those which are not well burnt, edges are irregular and surface quite rough. It uses for interior part and temporary building structures. Water absorption capacity will go up to $25 \%$ and minimum compressive strength is $3 \mathrm{MPa}[10]$.

\subsection{Relationship Between Affecting Factors and Brick Characteristics}

The physical and mechanical characteristics of bricks can be controlled to a significant extent by varying the affecting factors mainly composition of the raw clay and the firing temperatures [21].

\subsubsection{Effect of Clay Composition on Characteristics of Bricks}

i) Clay composition and brick sizes

Lime pop appears on brick surface if clay particles are not mixed homogeneously and left some lumps on it. The clay with high sand makes brick less cohesive, weak and broken corner. It was reported that type of clay brick samples collected from Kathmandu valley were identified as quartz, feldspars, mica mineral and hematite, and such clay bricks are considered to be fired at $900-1000^{\circ} \mathrm{C}$ [22]. Improper mixing proportion of clay particles creates shrinkage or expansion. It was revealed that shrinkage on firing of clays is affected by clay composition [23]. Approximately $80 \%$ of USA brick do not use raw materials that contain calcite because such refractory material may not develop sufficient fusion at normal brick firing temperatures and cause enormous expansion in brick volume [14].
Similarly, it was found lower shrinkage in carbonaceous clay than the clay without carbonates at the same temperature and firing time [12]. For non-calcareous clays, a firing temperature of $1000^{\circ} \mathrm{C}$ is high enough to produce bricks, while $1100^{\circ} \mathrm{C}$ is required in case of calcareous clays [21]. Also, when calcareous clays are used, the content of carbonates should be controlled in order to avoid "lime blowing" effect [21].

ii) Clay Composition to bulk density and water absorption capacity

Bulk density is the interrelation of weight and volume, so shrinkage or expansion of bricks due to clay composition affects bulk density. Porous material has less weight and high density. But more compact brick is even broken.

Regarding clay composition and water absorption capacity $(\mathrm{w} \%)$, the brick with high sand particles are more porous and have high water absorption capacity.

iii) Effect of clay composition for compressive strength

The brick is homogeneous, harder and stronger due to the ceramic bond from the sintering phase of the silica and alumina clay constituents [6]. The composition proportion of clay particles also depends on location. Different firing temperature need to be applied for different types of brick clay at different composition. For example: the optimum firing temperature for the production of clay bricks using clay soils from site A was $970-1200^{\circ} \mathrm{C}$ while for the bricks from site $\mathrm{B}$ is from $900-970^{\circ} \mathrm{C}$ [15].

\subsubsection{Effect of Kiln Types}

Kiln types affect bulk density, water absorption capacity (w\%) and compressive strength. The position of bricks inside kiln (Figure 5) determines water absorption and compressive strength [18] as shown in (Table 3) below.

Table 3. Position of brick inside the kiln affect brick properties.

\begin{tabular}{llll}
\hline \multirow{2}{*}{ Position of brick inside the kiln } & Dry pressed brick & \\
\cline { 2 - 4 } & Compressive Strength $(\mathbf{M P a})$ & Density $\left(\mathbf{k g} / \mathbf{c m}^{\mathbf{2}}\right)$ & Water absorption $(\mathbf{\%})$ \\
\hline Top & 71.019 & 2.02 & $9 \%$ \\
Top $1 / 3^{\text {rd }}$ & 60.262 & 2.00 & $11 \%$ \\
Bottom $1 / 3^{\text {rd }}$ & 40.956 & 1.95 & $12 \%$ \\
Bottom & 23.995 & 1.88 & $15 \%$ \\
\hline
\end{tabular}

\subsubsection{Effect of Firing Time Firing Time and Compressive Strength}

The combine application of proper firing time and temperature heavily effect on the characteristics on produced brick. But, if the temperature is kept constant and only vary the duration of firing time from 2 to $8 \mathrm{~h}$, there is only a slight increase in the compressive strength and minor decrease in the water absorption [15]. This means that firing time shows less effect than firing temperature. But slow and steady application of heat is necessary for quality brick production. Many studies showed that application of high heat in short period of time is good to produce quality bricks, but rapid firing causes the bloating of clay due to the formation of an impermeable vitrified outer skin which affects brick quality
[20]. Cutoff in firing time is important in case of high heat application to protect bricks from over burnt. It is not necessary to apply longer heating time as it does not help to increase density, water absorption and compressive strength, but it will be uneconomical only [20, 21].

\subsubsection{Effect of Firing Temperature}

i) Firing temperature to brick volume: Firing temperature significantly affect the physical requirements of fired bricks. Length change, shrinkage and expansion occurs during the warming-cooling cycle for specimens fired at temperatures between $900-1100^{\circ} \mathrm{C}$ where, very well fired brick, expanded slightly at $1100^{\circ} \mathrm{C}$ instead of shrinking [23]. The brick size structure formed at lower temperatures $\left(840^{\circ} \mathrm{C}-960^{\circ} \mathrm{C}\right)$ remained essentially the same until temperatures went over 
$1080^{\circ} \mathrm{C}$. Researchers also reported that the shrinkage values for clay bricks fired at temperature $800^{\circ} \mathrm{C}, 900^{\circ} \mathrm{C}$ and $1000^{\circ} \mathrm{C}$ were $0.31 \%, 0.50 \%$ and $1.04 \%$, respectively, where the value increased by $74 \%$ from temperature $1000^{\circ} \mathrm{C}$ to $1100^{\circ} \mathrm{C}$ due to the reduction in volume [24].

ii) Firing temperature to bulk density and water absorption capacity: The bulk density and firing shrinkage of brick increased with the increasing firing temperature while heating the brick from 700 to $1100^{\circ} \mathrm{C}$ [20].

Water absorption capacity of the fired clay bricks decreased with the increase in the firing temperature [15]. Water absorption decreased significantly when the temperature increased due to the formation of the amorphous silica at high firing temperatures $[25,26,20]$. The bricks that were sintered below $1000^{\circ} \mathrm{C}$ are considered as a porous structure since their water absorption rates are higher than $25 \%$ [24].

iii) Firing temperature to mechanical strength:

Compressive or mechanical strength increase with increase in firing temperature. A study showed that compressive strength increased more than double while firing the bricks from 700 to $1200^{\circ} \mathrm{C}$ [15]. Compressive strength of brick is remarkably improved at higher temperatures as it increased from $31.1 \%$ to $253.3 \%$. at firing temperature ranged $700-800^{\circ} \mathrm{C}$; and 700 $1100^{\circ} \mathrm{C}$ respectively [20]. Such sharp increase in strength at $1000^{\circ} \mathrm{C}$ and above may be due to the enhanced vitrification in the clay materials.

\subsection{Other Factors Affecting Quality of Brick}

\subsubsection{Social Factors}

Labors safety, welfare and child labor related social issues have been raised in brick production industry. The social issues about using brick clay in vicinity of the factories are: top soil degradation and soil fertility. Land Use Policy, 2069 (2012) in Nepal support on those issues for making quality soil adequately available to use for brick production purposes [44]. Transportation of soil from other place may add the cost of production as well as issues about storage facilities and associated emission from the soil.

\subsubsection{Economic Factors}

The quality of brick produced also depends an economic factor. The total cost involve in brick production process are: Capital expenditures including the costs of equipment and its installation; Energy costs, which are the costs of electricity and burning fuels; Labor costs, including the costs associated with employees' wages and benefits; and The cost of other materials like clay minerals, parts, and additives etc.[52].

\subsubsection{Environment Factors}

Despite producing one of the most preferred building materials, brick kilns are criticized for their negative impacts on environment. Particulate matter (PM), black carbon (BC), Sulphur di-oxide $\left(\mathrm{SO}_{2}\right)$ and carbon di-oxide $\left(\mathrm{CO}_{2}\right)$ are some of the most common emissions credited to brick kiln. Brick kilns have been identified as the fourth largest source of air pollution in Kathmandu Valley as about $11 \%$ of the total PM emission is from the brick factories [27]. Similarly, the study carried out by the World Bank in 1996 showed that brick kilns are the number one emitter of sulfur-dioxide [28, 29].

The choice of brick kiln heavily depends its emission rate. Movable Chimney Bull Trench Kiln (MCBTK) in Nepal was banned in 2004 due to its high emission status [17].

Moreover, farmers have experienced the problems of drying water sources, low water holding capacity on soils, poor crop stability and reduced crop productivity. To recover the level of production, farmers are now applying high doses chemical fertilizers, which have harmful consequences to ecological system [30]. It has serious impacts on physical, biological, and chemical properties of soil resulting sharp declination in soil fertility and productivity [31]. Brick fields are considered as the principle reason of top soil degradation and environmental pollution of the area [30]. Hence, availability and adequacy of brick clay could be a challenge for many brick producers who do not owned or leased big land.

\subsubsection{Brick Related Policy}

\section{Brick Related Policy in Nepal}

The government of Nepal (GoN) is aware of the serious environmental and social problems created by the brick kilns. Though, there are no policies or regulations that are exclusively targeted to brick quality in Nepal [29], some policies about brick sector are interlinked with other policies, rules, and regulations. Mainly type of brick kilns and environment pollution related policies have been promulgated in Nepal like: 'The Environment Protection Act 2053 (1996)', and 'The environment Protection Rules 2054 (1997)'. High emission intensive kilns are forced either to "clean up" or" close down" [16]. Other relevant policies [29] are:

1) National Ambient Air Quality Standards, 2069 (2012)

2) Standard on Chimney Height and Emission for Brick Kiln Industry, 2064 (2008)

3) Provision for Initial Environment Examination (IEE), and Environment Impact Assessment (IEA).

4) Brick Company Registration process based on new Industrial Enterprise Act, 2073.

5) Ban operation of non-registered and high emission intensive brick kilns.

6) GoN recognized VSBK technology is a non-woodbased technology, which is a step towards promoting efficient and cleaner technologies.

Brick related Policy in global context

India banned MCBTK in 1996, where Nepal banned it in 2004, and introduced emission standard for VSBK kiln. Europe banned tall chimney because of acid rain issue, and Bangladesh banned FCBTK, and use of agricultural soil (32). Likewise, South Africa applied the provision of giving government incentive to move from energy inefficient clamps to cleaner technology carbon tax on brick sector [32].

The mostly used fuel for brick firing is coal. In case of Nepal, about $70 \%$ of total burning fuel in kilns is coal $(30 \%$ is - bagasse, saw dust, biomass etc.) which is imported from India [33]. So, it is unreliable and costly too. Besides, there is 
no any quality checking system for coal has been applied yet, due to the fact high emission from kilns is awfully experiencing in Kathmandu Valley [16].

\section{Methodology}

\subsection{Research Approach}

A mixed method approach was used for data collection. Qualitative data, both primary and secondary, was collected through site observation and literature review. Quantitative data was collected through lab experiment (Figure 7). The benefits of using of both methods is increment of findings validity.

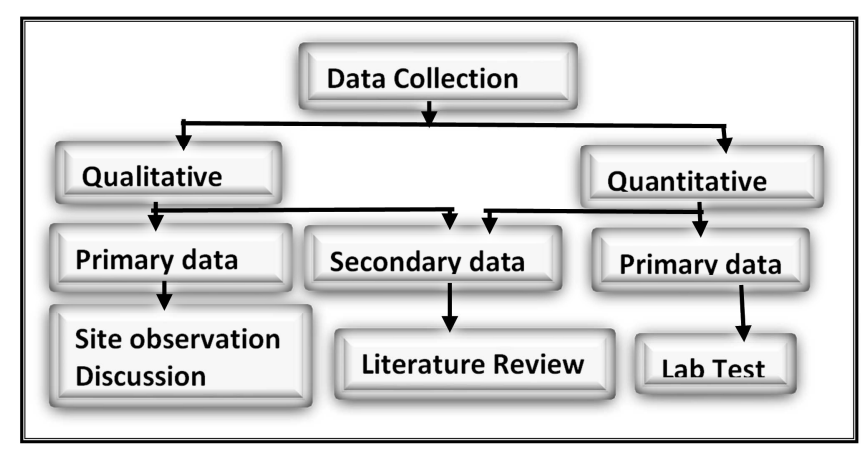

Figure 7. Research methodology applied for data collection.

\subsubsection{Sample Collection}

By using purposive sampling method, the factories for brick sample collection were selected in Bhaktapur and Lalitpur districts in Kathmandu Valley, Nepal. The purposive sampling technique, which is also called judgment sampling, is a non-random technique that does not need a set number of informants, but the researcher decides what needs to be known and sets out to find people who can and are willing to provide the information based on their knowledge or experience $[34,35]$. It is a practical, effective and efficient tool than random sampling [36].

Out of 110 brick kilns in Kathmandu Valley- 15, 32 and 63 are situated in Kathmandu, Bhaktapur and Lalitpur district respectively. Six brick factories are randomly selected for this study by using purposive sampling method. The six branded bricks are namely UK (Sample 1 or S1); Kalash (Sample 2 or S2); HOT (Sample 3 or S3); DYK (Sample 4 or S4); COM (Sample 5 or S5); and TATA (Sample 6 or S6), all from Lalitpur and Bhaktapur districts in Kathmandu, Nepal (Table 4).

\subsubsection{Site Observation, Formal and Informal Discussions}

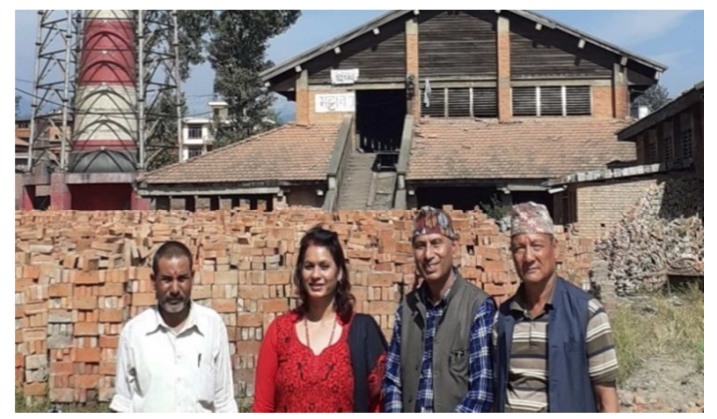

Figure 8. Brick site visit and discussion with officials.
The researcher observed the brick factory site during brick production, and carried out formal and informal discussions with relevant people to get information about the brick production, mainly about types of kiln used, heating time, approximate heating temperature, availability of clay, and some social \& environment aspects. Respondent for discussion were from factory officials, technicians, and brick users. (Figure 8). Checklist was prepared and verified before go to the field.

\subsubsection{Lab Experiment}

The experiment was carried out under controlled laboratory conditions in Civil Engineering Material Lab at Institute of Engineering Pulchowk Campus, Kathmandu Nepal. The experiment was followed according to different standard codes. During the experiment process, all brick samples were boiled, dried, weighted, measured and compressed. Five number of samples were taken for each brand, completed individual tests for each brick and took average value of bulk density, water absorption and compressive strength for each brand. Uni-axial compressive test method with varying load was applied to measure compressive strengths. Then, comparative analysis is performed to assess the result with codes and previous findings, and finally the literatures were referenced to discuss policies about quality brick production.

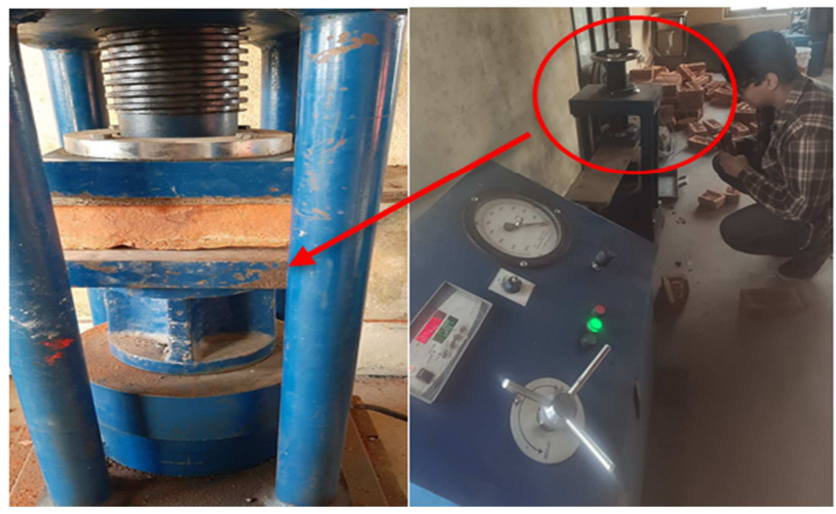

Figure 9. Compressive Strength Test of Brick Samples.

(i) Brick Dimension: Brick Size Test

Procedures followed: The dimension of all brick samples were measured both at: a) normal; and b) after soaked in cold water for 24 hours and boiled for 5 hours' condition. The measured value for each sample was an average value of five samples from each brand, were compared with standard dimension as shown in (Table 5) below.

(ii) Bulk Density Test

Procedures followed: The American Society for Testing Materials- ASTM Standard Code was followed for density test $[45,47,51]$. According to it, all brands of the brick specimens were measured and weight at normal condition (w1). Then boiled 5 hours and soaked in cold water for next 24 hours, and observed weight (w2). Bulk density was calculated by using equation 1 .

(iii) Water Absorption (W\%) Test 
Procedures followed: “IS: 3495 (Part II - 1992 (R2002) \& ASTM C67 Codes was followed for water absorption test [45, 46]. For this test, all sampled bricks were boiled 5 hours and soaked in cold water for 24 hours, and took wet weight (w1). (The same specimens were taken hereafter for bulk density test). Then, they keep in dryer at about $200^{\circ} \mathrm{C}$ for next 24 hours and took dry weight (w2). The w\% of the brick sample was calculated by using equation 2 .

(iv) Compressive Strength test

Procedures followed: IS: 1077 -1992 (R2002), NBC109: 1994 Code was followed for compressive strength test of the bricks $[46,47]$. The same samples were taken after weighing the specimens for water absorption capacity test. Then, the frogs and all voids in the bed faces were filled with cement mortar (OPC cement grade 50 and clean coarse sand of grade $3 \mathrm{~mm}$ at 1:1 proportion). Then the bricks were put in oven at about $200^{\circ} \mathrm{C}$ for next 24 hours, took them out, and left for cooling for next 3 hours before use for test. The Universal Compression Testing Machine (Intron 4505) was set in the lab. Brick specimens were put in the machine with flat plates support at the top and the bottom for even surface. Then applied uniaxial load at a uniform rate of $14 \mathrm{~N} / \mathrm{mm}^{2} /$ minute and noted the maximum load at which specimen was failed (Figure 9). Intron digital recorder was fitted in the computer for auto recording of the result. The compressive strength was calculated by using equation 3 .

\subsection{Data Analysis}

After completing all lab experiments by following the procedures as explained in Section 3 above, the observed result data were calculated and presented in tables and figures in Section 4. Microsoft Word, MS Excel, and simple Statistical Tools and Charts were used for data presentations. The measured Dimensions of bricks were compared with standard brick sizes as per NBC 205: 1994) of Nepal (Table $(2,5)$ and represented in bar charts in Figures [10 (a), (b), and (c)]. Bulk Density of sampled bricks, both at dry and wet states, were calculated by using Equation 1 [Section 2.2 (ii)], and presented in Table 6. Similarly, Water Absorption Capacity (w\%) was calculated by using Equation 2 [Section 2.2 (iii)] and presented in Figure 11. Likewise, the Compressive Strength of tested bricks was calculated by using Equation 3 [Section 2.2 (iv)] and presented in Figure 12. Finally, all results were shown in a comparative bar chart in Section 5 in Figure 13. The relevant characteristics value of bricks from literature and standard codes were presented in Table 7, on the basis of which discussion on the results was done comparatively with the threshold value of the tested bricks.

\section{Results and Discussion}

During site observation, qualitative data about sampled bricks was collected through discussion with company officials and technicians (Figure 8). There is not any temperature record keeping devices found installed, neither any studies have been done about those brick brands (Table 4). Though, technician manages firing temperature manually in his/ her own way. Figure 6 (a), (b).

Table 4. Information taken from the site observation.

\begin{tabular}{lllll}
\hline Brick Sample & Location & Type of Kiln & Color & Temp Gauge \\
\hline S1 & Bungmati, Lalitpur & FCBTK & Light Red & Not Fitted \\
S2 & Godavari, Lalitpur & FCBTK & $"$ & $"$ Not Done Yet \\
S3 & Jagati, Bhaktapur & FCBTK & $"$ "s \\
S4 & Sudal, Bhaktapur & FCBTK & $"$ \\
S5 & Thampimai, Lalitpur & FCBTK & $"$ & $"$ \\
S6 & Harisiddhi, Lalitpur & FCBTK & $"$ & $"$ \\
\hline
\end{tabular}

\subsection{Lab Test Results and Discussion}

\subsubsection{Size of Bricks}

Dimension of all brick specimens: measured Length (L), measured Breadth (B), and measured Height (H), were measured in the lab both at normal and soaked in water conditions. The relative standard value for $\mathrm{L}, \mathrm{B}$, and $\mathrm{H}$ are also presented in here in Table 5 and Figure 10 (a), (b,) (c).

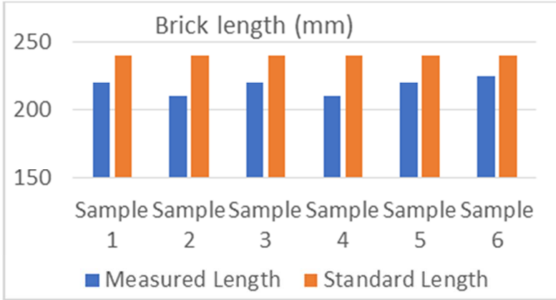

(a)

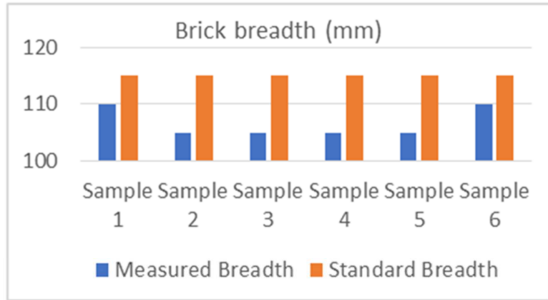

(b)

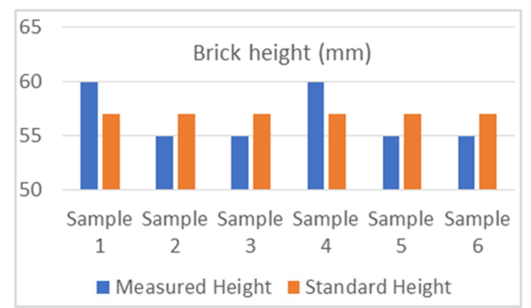

(c)

Data source: Lab experiment result

Figure 10. (a), (b), (c): Dimension of Brick specimens. 
Table 5. Measured and code dimension of bricks.

\begin{tabular}{|c|c|c|c|c|c|c|}
\hline \multirow{2}{*}{ Brick Specimen } & \multicolumn{6}{|c|}{ Dimension of brick (mm) } \\
\hline & $L$ & Code & $B$ & Code & $\boldsymbol{H}$ & Code \\
\hline Sample 1 & 220 & \multirow{6}{*}{240} & 110 & \multirow{6}{*}{115} & 60 & \multirow{6}{*}{57} \\
\hline Sample 2 & 210 & & 105 & & 55 & \\
\hline Sample 3 & 220 & & 105 & & 55 & \\
\hline Sample 4 & 210 & & 105 & & 60 & \\
\hline Sample 5 & 220 & & 105 & & 55 & \\
\hline Sample 6 & 225 & & 110 & & 55 & \\
\hline
\end{tabular}

It showed that none of the brands followed standard brick size as per NBC109-1994 [47]. The technical reasons behind such undersized brick might be either: a) cutting wires was set wrongly, b) die or mold was small; c) high clay content to excessive drying shrinkage; and d) over burned or firing shrinkage. The possible solution might be: a) either add sand; b) use less fuel or low temperature; or c) reduce firing time.

\subsubsection{Bulk Density}

Bulk density of bricks was measured both at dry and wet state as shown in (Table 6) below.

Table 6. Bulk density of sampled bricks $\left(\mathrm{g} / \mathrm{cm}^{3}\right)$.

\begin{tabular}{|c|c|c|c|c|c|c|c|}
\hline Brick Samples & & S1 & S2 & S3 & S4 & S5 & S6 \\
\hline & Dry State & & & & & & \\
\hline Weight (g) & & 1950 & 2180 & 2000 & 2210 & 1710 & 2100 \\
\hline Volume $\left(\mathrm{cm}^{3}\right)$ & & 1452 & 1212.7 & 1270.5 & 1323 & 1270.5 & 1361.3 \\
\hline Bulk Density & & 1.34 & 1.80 & 1.57 & 1.67 & 1.35 & 1.54 \\
\hline & Wet State & & & & & & \\
\hline Weight (g) & & 2050 & 2300 & 2240 & 2300 & 1870 & 2250 \\
\hline Volume $\left(\mathrm{cm}^{3}\right)$ & & 1452 & 1320 & 1391.5 & 1210 & 1331 & 1442.1 \\
\hline Bulk Density & & 1.41 & 1.74 & 1.61 & 1.90 & 1.40 & 1.56 \\
\hline
\end{tabular}

Data source: Lab experiment results

The result of this study showed that dry density varied from 1.34 to $1.82 \mathrm{gm} / \mathrm{cm}^{3}$, and wet density varied from 1.40 to $1.90 \mathrm{gm} / \mathrm{cm}^{3}$. The value of wet density is higher due to fill of pores/voids with water. The brands S1 with S5; and S6 with S3 showed similar density below $1.8 \mathrm{gm} / \mathrm{cm}^{3}$ except only one sample S4.

The density for standard bricks varies from 1.8 to 2.4 $\mathrm{gm} / \mathrm{cm}^{3}$ as per [51]. But it was also found that the density varied from 1.55 to $2.82 \mathrm{gm} / \mathrm{cm}^{3}$ for the brick samples produced in Bhaktapur [9]. Likewise, bulk density of clay bricks was found 1.61 to $1.77 \mathrm{gm} / \mathrm{cm}^{3}$ at firing temperature range from $700-1100^{\circ} \mathrm{C}$ [20]. Similarly, bulk density of brick was about $2 \mathrm{gm} / \mathrm{cm}^{3}$ in average [26]. Moreover, the value ranged 1.2-1.8 $\mathrm{gm} / \mathrm{cm}^{3}$ as revealed by [6].

Comparing all those results it can be concluded that the quality of all sampled brick brands seemed less in bulk density than the threshold value. It might be due to the under size of bricks.

\subsubsection{Water Absorption Capacity}

The result showed that water absorption capacity of brick samples varied from $4 \%$ to $12 \%$ (Figure 11 ). The maximum water absorption percentage at 5 -h boiling condition is 20 to $25 \%$ [51]. Some researchers found it, 10 to $28 \%$ [6] and, 9 to $23 \%$ [9]. So, water absorption capacity seems okay for all tested samples.

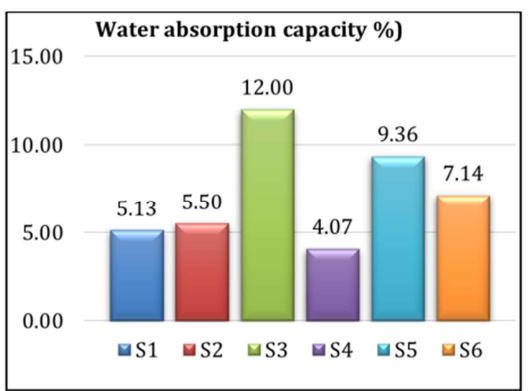

Data source: Lab experiment result

Figure 11. Water absorption of sampled bricks.

\subsubsection{Compressive Strength}

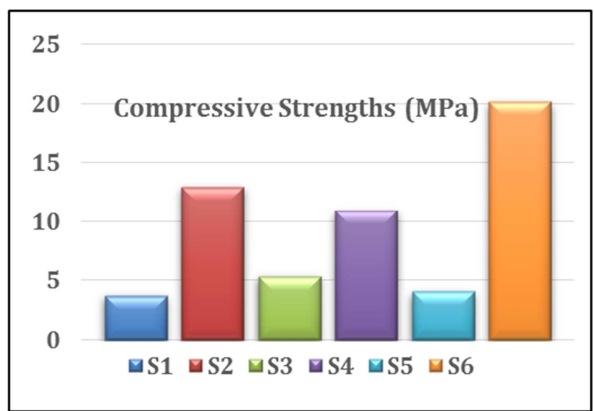

Figure 12. Compressive strength of sampled brick. 
The result of this study showed that the compressive strength of brick specimens varied from 3.72 to $20.16 \mathrm{MPa}$ (Figure 12) which is within the allowable limit. Comparatively, Sample 1 has the lowest strength, while Sample 6 has the highest one. Compressive strength values of all brick specimens were found within the given code values of $3.5 \mathrm{MPa}$, though about $50 \%$ of tested brand bricks showed strengths below $5 \mathrm{MPa}$.

Compressive strength of sampled bricks at different weathering condition (Strong Weathering (SW). Moderate Weathering (MW) and Negligible Weathering NW) was ranged 10.3 - 20.7 $\mathrm{MPa}$ [21]. Similarly, it is known that the minimum compressive strength required in Spain is $10 \mathrm{MPa}$ [21]. Likewise, Compressive strength also varied from: 16.10 - 28.90 MPa [41] and from 11.12 to $13.73 \mathrm{MPa}$ too [42]. The compressive strengths of all the brick samples from
Kathmandu Valley were found to be in the range of 5 - 23 $\mathrm{MPa}$ [6]. In addition to this, the crushing strength of bricks produced in Bhaktapur, found between $7.83 \mathrm{MPa}$ to 22.10 $\mathrm{MPa}$ [9].

Compressive strength varies from 3.5 to $35 \mathrm{MPa}$ as per their grade (IS1077: 1992) [49], and all the above studies showed their result within this value range. No exception, the result of this study followed the same trend as of many previous studies $[6,9]$.

\subsection{Comparative Analysis}

The comparative result value for each brick characteristics of tested bricks and codes and previous findings are presented in (Table 7) below.

Table 7. Comparative analysis of brick characteristics with respect to standard code and previous findings.

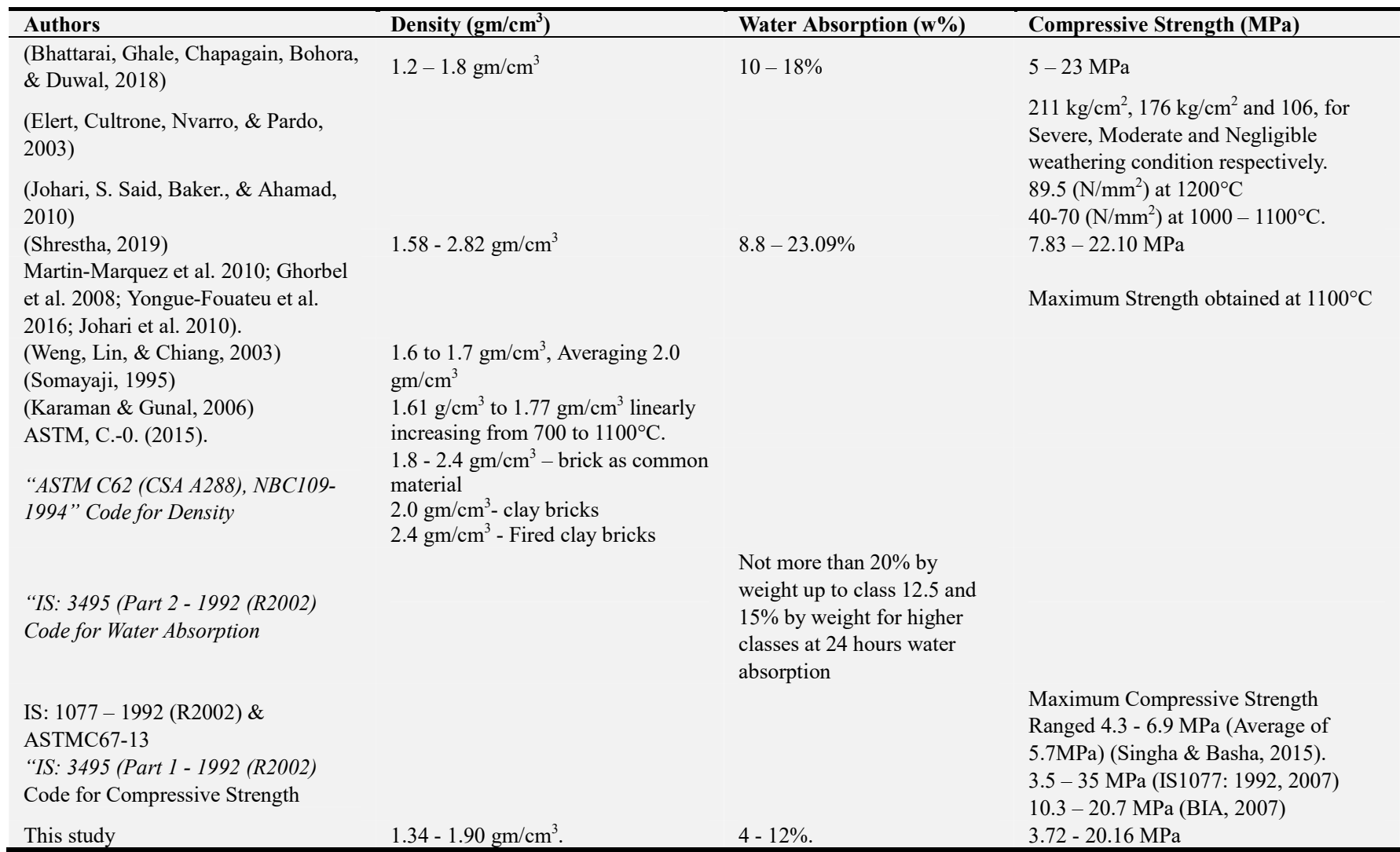

\section{Conclusion}

This study, and also other literatures, showed that the soil composition, types of kiln, firing time and firing temperature are the major affecting factors in quality brick production.

This study revealed that the brick samples having low water absorption capacity have high bulk density and high compressive strength. Sample No. 6 has maximum compressive strength ( $>20 \mathrm{Mpa})$, water absorption value $(<15 \%)$ but low density (mostly below $1.8 \mathrm{~kg} . \mathrm{cm}^{2}$ (Figure 13 ). All bricks are found undersized. The reason behind it might be shrinkage due to over burnt, though it has not been affected to water absorption capacity.

The types of soil available in Kathmandu are Quartz. Felspar etc., that needs $900-1000^{\circ} \mathrm{C}$ firing temperature, might cause for over burnt. There are all three classes of bricks found in those six brand samples as their strengths varied from 3.5 to $20 \mathrm{MPa}$, though, $50 \%$ of sample showed strengths below 5 $\mathrm{MPa}$ ( $3^{\text {rd }}$ class brick). However, the test result might be influenced by some other factors like testing techniques, test apparatus, boundary conditions, shape and dimension of samples etc. as experienced by Bati and Ranocchiai in [37]. Nevertheless, such marginal range showed that extra attention should be paid for maintaining and upgrading the quality before they approve to use for construction. 


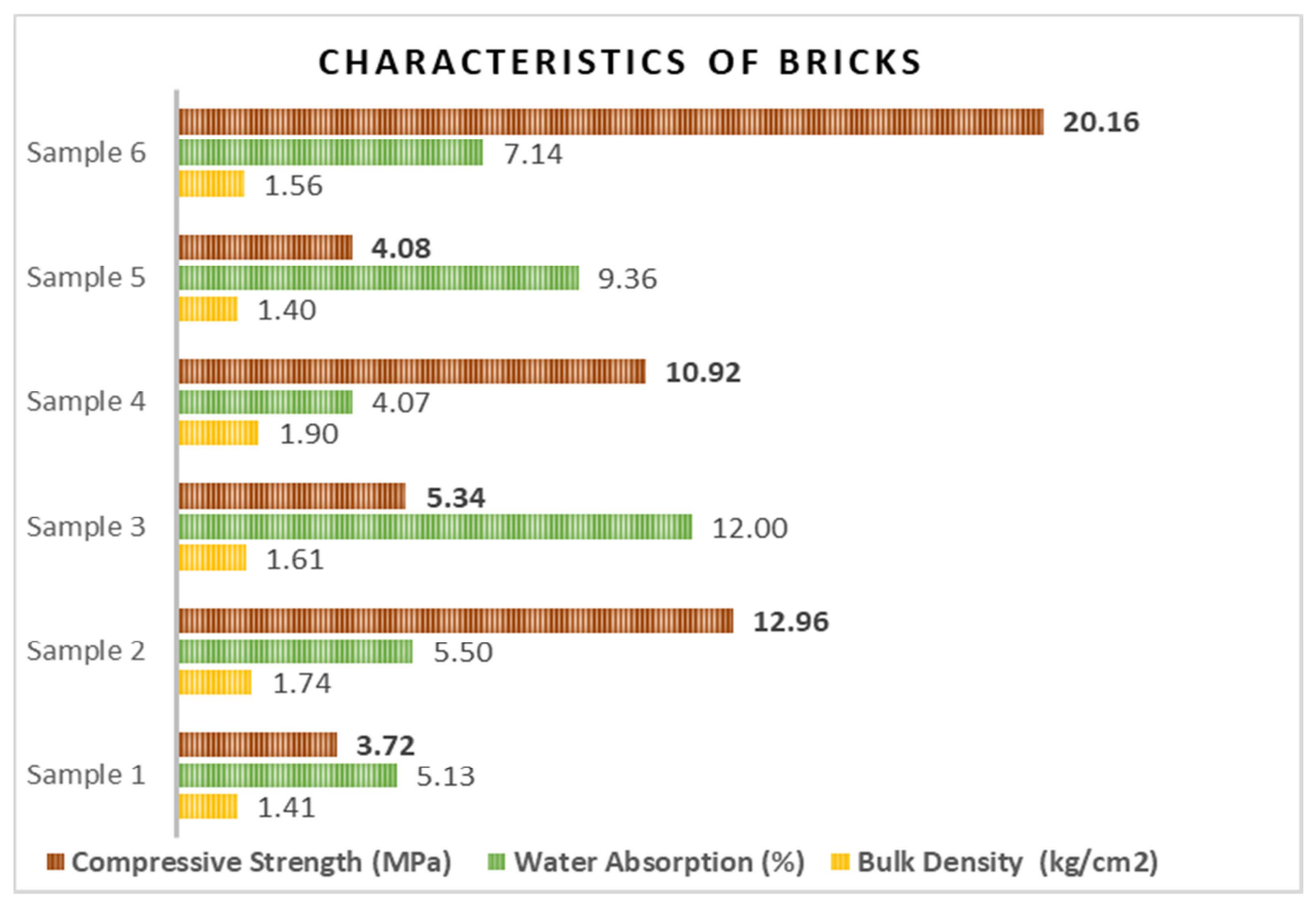

Figure 13. Brick test result and summary of its characteristics.

Even though, the government of Nepal is aware of the serious environmental and social problems created by the brick kilns, there have been confronting a number of inherent issues about kilns. Despite the soil degradation related issue is included in the National Land Use Policy (2012) in Nepal, social issues have been raised yet about brick kilns near agricultural land as they are still leading to soil degradation and soil fertility. Transportation of brick soil from other places may not be sustainable in terms of both economic and reliability perspectives.

\section{Recommendations}

This study suggested that brick manufacturers should get and use proper brick clay raw materials and to be assured for quality brick production.

It is recommended to review existing standards for solid bricks and make mandatory provision to use standard brick size in public construction. Enforcement and implementation of legislation for quality brick production should still be applied strictly.

Brick manufacturers are strongly recommended to select

an appropriate kiln type for brick production because it helps save environment, increase production efficiency, and improve brick quality.

One of the recommendations the study would like to recommend is that it would be better if TKs kiln, which are low emission intensive and high efficiency type kiln, were used instead of FCBTKs.

Any branded bricks that have strengths below $5 \mathrm{MPa}$ should not be recommended to use for major construction works.
Technical know-how of the stakeholders (manufacturers and consumers) on the brick production technology and quality parameters of bricks should be enhanced so that production and use of quality bricks would be better practiced that would eventually contribute to maintaining safe and sustainable infrastructure

Finally, the study also suggested further studies on types and proportion of soil; the firing temperature measurement system; and the effectiveness of alternative fuel than coal for brick burning on which this study could not done in detail.

\section{References}

[1] Bohora, N. B., Bhat, L. B., Ghale, D. B., Duwal, N., \& Bhattarai, J. (2019). Investigation of the Firing Temperature Effects on Clay Brick of Kathmandu Valley (Nepal) Part I Mineralogical Phase Characterization. BIBECHANA, A Multi-disciplinary Journal of Science, Technology and Mathematics, 16, 122-130. Retrieved 2018, from http://nepjol.info/index.php/BIBECHANA.

[2] Nepal, S., Mahapatra, P. S., Adhikari, S., Shrestha, S., Sharma, P., Shrestha, K. L.,... Puppala, S. P. (2019). A Comparative Study of Stack Emissions from Straight-Line and Zigzag Brick Kilns in Nepal. 10 (107). doi: 10.3390/atmos 10030107

[3] Manandhar, U., \& Dangol, S. (2013). Study on Evaluating Energy Conservation Potential of Brick Production in SAARC Countries; A Report on Nepal; SAARC Energy Centre. Islamabad, Pakistan.

[4] Ulak, N. (2015). Nepal's Earthquake-2015: Its Impact on Various Sectors. Journal of Tourism and Hospitality, 7, Pp. 129. 
[5] Pariyar, S. K., Das, T., \& Ferdous, T. (2013). Environment and Health Impact for Brick Kiln in Kathmandu Valley. International Journal of Scientific and Technology Research, 2 (5).

[6] Bhattarai, J., Ghale, D. B., Chapagain, Y. P., Bohora, N. B., \& Duwal, N. (2018, December). Study on the Physical and Mechanical Properties of Ancient Clay Brick Samples of Kathmandu Valley, Nepal. Tribhuvan University, Nepal, 32 (2). Retrieved 2020.

[7] Raut, A. (2003). Brick kilns in Kathmandu Valley. Current Status, Environment Impact and Future Options. Himalaya Journal of Science, 1 (1), Pp 59-61.

[8] Tuladhar, B., \& Raut, A. (2002). Environment and Health Impact of Kathmandu's Brick Kilns, Clean Energy Nepal (CEN).

[9] Shrestha, S. (2019). A Case Study of Brick Properties Manufacture in Bhaktapur. Journal of Science and Engineering, 7, Pp. 27-33.

[10] Rajput, A. K. (2010). Engineering Material (Third Edition ed.). S. Chand and Company Limited, 7361 Ram Nagar, New Delhi 110-055.

[11] Akinshipe, G., \& Kornelius, O. (2017). Chemical and Thermodynamic Processes in Clay Brick Firing Technologies and Associated Atmospheric Emissions Metrics - A Review. Journal of Pollution Effects \& Control, 5 (2). doi: 10.4176/2375-4397.1000190.

[12] Dondi, M., Marsigli, M., \& Venturi, I. (1999, January). Microstructure and Mechanical Properties of Clay Bricks: Comparison Between Fast Firing and Traditional Firing. British Ceramic Transactions, 98 (1), Pp 1218.

[13] Johari, S. B. (2010). Effect of the Change of Firing Temperature on Microstructure and Physical properties of Clay Bricks from Berous. Science of Sintering, 42 (2), 245254. doi: http://doi.org/10.2298/SOS1002245J.

[14] Robinson, C. G., \& Borchelt, G. (1994). Factors Influencing Clay Brick Durability. 10th IB Mac Calgary, Canada.

[15] Tsega, E. M. (2017). Effects of Firing Time and Temperature on Physical Properties of Fired Clay Bricks. American Journal of Civil Engineering, 5 (1), Pp. 21-36.

[16] SMS. (2017). Brick Kiln Stack Emission Monitoring in Kathmandu Valley. Report submitted to Government of Nepal Ministry of Population and Environment Lalitpur Nepal by SMS, Environment and Engineering Pvt. Ltd. Mahalaxmi -16, Imadole, Lalitpur Nepal.

[17] Shah, D. P., Chaudhari, S., Shakya, R., Shah, P. K., \& Mishra, A. K. (2019). Status of Brick Kilns Stack Emission in Kathmandu Valley of Nepal. Journal of Advanced Research in Civil and Environmental Engineering, 6 (3\&4), Pp 1- 9.

[18] Laffer, D. B. (2004). Engineering Properties of Historic Brick: Variability Considerations as a Stationary Versus NonStationary Kiln Types. Journal of the American institute of Conservation, 43 (3), Article 4, pp. 255-272.

[19] Presertsan S., T. T. (1995). A Study Towards Energy Saving in Brick Making, Part 1: Key Parameters for Energy Saving. RERIC Int Energy J., 17 (2), 145-156.

[20] Karaman, S. I., \& \& Gunal, H. (2006). Firing Temperature and
Firing Time Influence on Mechanical and Physical Properties of Clay Bricks. Journal of Science and Industrial Research, 65, 153-159. doi: http://nopr.niscair.res.in/handle/123456789/4811.

[21] Elert, K., Cultrone, G., Nvarro, C. R., \& Pardo, E. S. (2003). Durability of Bricks Used in the Conservation of Historic Buildings - Influence of Composition and Microstructure. Journal of Cultural Heritage, 4, Pp 91 -99.

[22] Ghale, D., Bohora, N., Duwal, N., \& Bhattarai, J. (2018). Investigation on the Mineralogical Phase of Ancient Brick Samples of Kathmandu Valley (Nepal) Using XRD and FTIR Analysis. Kathmandu: Rasaayan Journal of Chemistry (in press).

[23] Litvan, G. G. (1984). Determination of the Firing Temperature of Clay Bricks. American Ceramic Society Bulletin, 63 (4), Pp $617-18,627$

[24] Rani, J., Singh, K., Singh, R., \& Harish, S. (2015). Effect on Microstructure of Clay Bricks after Firing Temperature. JETIR (ISSN-2349-5162), 2 (10).

[25] Caltron, G., Sabastian, E., \& Torre, D. (2005). Construction Building Material, 19, Pp. 39.

[26] Weng, C., Lin, D., \& Chiang, P. (2003). Utilization of Sludge as Brick Materials. Adv Environ Res, 7, Pp. 679-685.

[27] Gautam. (2006). An Action Program on Air Quality Management of Kathmandu Valley. (2011). Industrial Policy.

[28] Prajapati, S. (2009). Studies on the Application of Renewable Solid Fuel Alternative to the Imported Coal Fuel in Vertical Shaft Brick Kiln- A Master's Thesis Submitted to Tribhuvan University, Nepal.

[29] Manadhar, U. M., \& Dangol, S. B. (2017). Study on Evaluating Energy Conservation Potential of Brick Production in SAARC Countries. SAARC Energy Centre, Islamabad. A Report on Nepal. Submitted by Min Energy Initiatives Nepal; ICIMOD; CCAC.

[30] Jerin, M., Mondol, S., Sarkar, B., Rimi, R., \& Aktar, S. (2016). Impacts of Brick Fields on Environment and Social Economy at Bagatipara, Natore, Bangladesh. J. Environ. Sci. \& Natural Resources, 9 (2), Pp, 31-34.

[31] Khan, H., Rahman, K., Abdur Rough, A., Sattar, G., Oki, Y., \& Adachi, T. (2007). Assessment of Degradation of Agricultural Soils Arising from Brick Burning in Selected Soil Profiles. International Journal Environmental Science and Technology, 4 (4), Pp. 471- 480.

[32] Yadav, N. K., \& Rahul, K. (2017). Overview of Brick Kiln Sector and Environmental Issues in the Country. Anil Agrawal Environment Training Institute, AAETI, CSE.

[33] Uprety, S., \& Lamichhane, B. (2016). HERD. A blog retrieved from http://www.herd.org.np/blogs/47.

[34] Bernard, H. (2002). Research Methods in Anthropology, Qualitative and quantitative methods. 3rd edition. Alta Mira.

[35] Lewis, J., \& Sheppard, S. (2006). Culture and communication: Can Landscape Visualization Improve Forest Management Consultation with Indigenous Communities. Landscape and Urban Planning, 77, Pp: 291- 313.

[36] Tongco, M. (2007). Purposive Sampling as a Tool for Informant Selection. Ethnobotany Research and Applications, Pp: 147-158. 
[37] Bati, B., \& Ranocchiai, G. (1994). A Critical Review of Experimental Techniques of Brick Material. Dipartimento di Costruzioni, Università di Firenze, piazza Brunelleschi 6 , 50121 Firenze, Italia. Calgary, Canada: 10th IB2 MAC.

[38] MoEST (2010) Environmental Pollution Control and Monitoring Section, Environment Division, Ministry of Environment Science \& Technology, Singhadurbar. A Brief Note, Kathmandu, 7.

[39] Vista, S. P., \& Gautam, B. (2018). Influence of Brick Processing on Changes in Soil Physico-Chemical Properties of Bhaktapur District, Nepal. International Journal of Chemical Studies, SP4: 146-150. doi: 10.13140/RG.2.2.29395.02088.

[40] Rana, S., \& Kumar, S. (2017). Brick Manufacturing: An Overview of Technology. Greentech Knowledge Solution Pvt. Ltd. Delhi, India.

[41] Kaushik, H. B., Rai, D. C., \& Jain, S. K. (2007). Stress-Strain Characteristics of Clay Brick Masonry under Uniaxial Compression. Journal of Material in Civil engineering, Vol 19.

[42] Phaiju, S., \& Pradhan, P. (2018). Experimental Work for Mechanical Properties of Brick and Masonry Panel. Journal of Science and Engineering, 5, Pp 51-57.

[43] NBC205. (1994).: 1994. Nepal National Building Code. Department of Urban Development and Building Construction, Kathmandu.

[44] MoLRM. (2015). Land Use Policy. Ministry of Land Reform and Management, Government of Nepal, Singhadurbar, Kathmandu.
[45] ASTM, C.-0. (2015). Standard Test Methods for Apparent Porosity, Water Absorption, Apparent Specific Gravity and Bulk Density of Burned Refractory Brick and Shapes by Boiling Water.

[46] IS. (1992 (b)). Bureau of Indian standard, Indian standard methods of test of burn clay building bricks-Part 2: Determination of water absorption, IS3495, 3rd Revision, New Delhi, India.

[47] NBC109. (1994). Nepal National Building Code. Department of Urban Development and Building Construction, Kathmandu.

[48] Shrestha, S., \& Thygerson, S. (2019). Brick Kilns of Nepal: A Non-Governmental Organization Perspective. Open Journal of Safety Science and Technology, 9, Pp. 1-6.

[49] IS1077: 1992. (2007). Common Burnt Clay Building Bricks Specification.

[50] ASTM. (2003). "Standard Test Methods for Sampling and Testing Brick and Structural Clay 363 Title" ASTM International, Pennsylvania, United States. C 67 - 03a.

[51] ASTMC62. (2006). Annual Book of ASTM Standards; C 62, Standard Specification for Building Brick (Solid Masonry Units Made from Clay or Shale). ASTM International, West Conshohocken.

[52] OAQPS. (2003). Economic Impact Analysis for the Brick and Structural Clay Products Manufacturing NESHAP: Final Rule. Environmental Protection Agency Office of Air Quality Planning and Standards. Innovative Strategies and Economics Group, MD-C339-01 Research Triangle Park, NC 27711. U.S. 